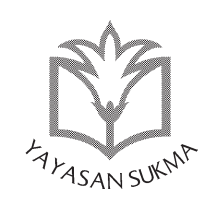

SUKMA: JURNAL PENDIDIKAN

ISSN: 2548-5105 (p), 9590 (e)

Volume 1 Issue 2, Jul-Dec 2017, hlm. 359-388

https://jurnalsukma.org/index.php/sukma/article/view/01206

\title{
STUDI KOMPARATIF \\ PENULISAN BACKGROUND SKRIPSI MAHASISWA BAHASA INGGRIS
}

\section{Ika Yatmikasari}

Universitas Islam Negeri (UIN) Sunan Gunung Djati Bandung, Indonesia

ikayatmikasari@gmail.com

\section{Abstract}

Academic writing for students should be a routine activity, but it is not easy especially that concerning with the writing of the background research that must meet certain criteria. This paper is the result of a review of the background section of English students' thesis which often has an unclear pattern. This paper compares the patterns (moves) developed in writing thesis backgrounds from two institutions and analyzes their advantages and disadvantages. The results show that basically the writing of background research has 
fulfilled the basic elements of the move, but rarely found complete move in one writing and the pattern is often not sequential.

[Menulis akademik (academic writing) bagi mahasiswa seharusnya menjadi aktifitas rutin, tetapi tidak mudah terutama menyangkut penulisan bagian latar belakang (background) yang harus memenuhi kriteria tertentu. Tulisan ini merupakan hasil kajian terhadap bagian latar belakang skripsi mahasiswa bahasa Inggris yang seringkali memiliki pola yang tidak jelas. Tulisan ini membandingkan pola (move) yang dikembangkan dalam menulis background skripsi dari dua institusi dan menganalisis kelebihan dan kekurangan tulisan dari masing-masing sumber objek. Hasil yang diperoleh menunjukkan bahwa pada dasarnya penulisan latar belakang penelitian sudah memenuhi unsur-unsur move yang seharusnya ada, tetapi jarang didapati move yang lengkap dalam satu tulisan dan pola yang ada sering tidak berurut.]

Katakunci: menulis akademik, menulis pendahuluan, move.

\section{Pendahuluan}

Menulis adalah bagian dari kegiatan ilmiah yang dilakukan oleh mereka yang menempuh pendidikan tinggi pada berbagai jenjang akademik termasuk S1. Bahkan dapat dikatakan bahwa menulis adalah bagian inti dari aktifitas belajar (Crème \& Lea, 2003: 2) karena sebagian besar tagihan atas tugas kuliah dituangkan dalam bentuk tulisan. Jenis tulisan yang seperti ini di dunia kampus lazim disebut sebagai academic writing atau tulisan akademik. Tulisan akademik berbeda dengan jenis tulisan lainnya terutama dalam hal tujuan, gaya (tone), dan unsur pembacanya (Oshima \& Hogue, 1999: 2). Salah satu bentuk tulisan akademik yang menjadi mahakarya mahasiswa adalah skripsi.

Menulis skripsi bagi mahasiswa Bahasa (atau Sastra) 
Inggris secara khusus memiliki tantangan tersendiri. Secara global, masalah yang sering kali muncul pada tahap penulisan skripsi adalah merumuskan masalah, mengumpulkan data, mencari referensi yang sesuai, mencari bukti yang mendukung penelitian, koherensi dan konsistensi, dan sitasi atau pengutipan (Litmoren, 2010). Masalah tersebut jika dirunut tampak tersebar di seluruh bab yang ada dalam skripsi. Dalam ruang lingkup yang lebih dekat, yakni di lingkungan tempat penulis mengajar, tantangan yang dihadapi mahasiswa saat mengerjakan skripsi meliputi masalah yang bersifat prosedural, akademik, dan non-akademik sebagaimana yang terungkap dari hasil penelitian yang dilakukan oleh Saehu (2008).

Khusus berbicara tentang bab pendahuluan, pengalaman penulis dalam membimbing skripsi menunjukkan bahwa mahasiswa seringkali menemukan kesulitan dalam menulis bagian background atau latar belakang penelitian. Hal ini bisa jadi sejalan dengan apa yang diutarakan oleh Swales \& Feak (2008: 242) sebagai berikut "writing introduction is slow, difficult, and troublesome for both native speakers as well as a non-native speakers". Dalam konteks menulis dalam Bahasa Inggris, ternyata hambatan itu tidak hanya dihadapi oleh penutur asing namum juga oleh penutur aslinya. Bagi mahasiswa, seringkali kesulitan itu muncul ketika menentukan apa yang sebaiknya mereka tulis lebih dulu sebagai pernyataan umum dan bagaimana merunutkanya secara spesifik hingga mengantarkannya pada pernyataan penelitian mereka.

Pertanyaan yang kemudian muncul adalah apakah permasalahan yang sama juga dihadapi oleh mahasiswa Sastra Inggris di perguruan tinggi lain? Pertanyaan ini menggiring pada gagasan untuk melihat permasalahan penulisan background di tempat yang berbeda dan membandingkannya dengan fenomena tersebut dengan yang terjadi di UIN Bandung. Penelitian ini sendiri difokuskan pada pola (atau move) yang dikembangkan dalam menulis background serta kelebihan dan kekurangan tulisan dari masing-masing sumber objek untuk kemudian dibandingkan satu sama lain. Melalui penelitian ini diharapkan permasalahan 
mahasiswa dapat diidentifikasi dengan baik, yang pada gilirannya dapat ditemukan solusi dan cara terbaik untuk membimbing mahasiswa ke dalam penulisan background yang tepat dan efektif.

\section{Landasan Teoritis}

Penulisan skripsi tidak terlepas dari prinsip penulisan karya ilmiah secara umum yang dikenal dengan istilah menulis akademik atau academic writing dalam Bahasa Inggris. Menulis akademik adalah kegiatan yang bertujuan untuk menghasilkan tulisan ilmiah. Penulisan akademik dijalankan secara ilmiah dengan merujuk pada prinsip-prinsip tertentu. Tulisan ini berbeda dari jenis tulisan yang lain, seperti tulisan sastra, jurnalistik, maupun bisnis terutama dalam hal target pembaca, gaya, dan tujuan (Oshima \& Hogue, 1999: 2). Pembaca mengacu pada siapa pihak yang akan membaca tulisan tersebut. Gaya adalah cara dalam mengekspresikan gagasan, yang biasanya tercermin dalam pilihan kata, pola gramatika tertentu, termasuk panjang pendeknya kalimat. Tujuan menentukan bentuk retorika dari suatu tulisan, semisal tulisan dengan genre eksposisi akan disusun secara berbeda dengan tulisan bergenre deskriptif.

Dalam menulis akademik, terdapat beberapa kerangka dan bagian-bagian yang harus dipatuhi. Kerangka dan bagian-bagian dari tulisan akademik ini selain berfungsi sebagai acuan dasar penulisan juga dapat mempermudah penulis untuk memaparkan alur tulisannya. Secara umum tulisan ilmiah memiliki struktur yang sama yakni pendahuluan, isi, dan penutup. Pendahuluan biasanya memuat topik secara umum, informasi dasar tentang topik yang akan dikembangkan, juga pernyataan atas topik yang akan diteliti (Zemach \& Rumisek, 2005: 71). Bagian penutup merangkum inti yang dibicarakan pada bagian isi, menyatakan kembali poin dari topik yang dikaji, memberikan tanggapan akhir tentang masalah yang telah diulas dan juga saran yang diberikan kepada pembaca (Zemach \& Rumisek, 2005: 74).

Khusus berbicara tentang latar belakang (research background) pada bab pendahuluan, bagian ini menempati posisi 
yang pertama dan penting dalam sebuah skripsi. Latar belakang masalah penelitian menjelaskan secara lengkap topik (subject area) penelitian, masalah penelitian yang kita pilih dan mengapa melakukan penelitian pada topik dan masalah tersebut (Berndtsson et al., 2008). Bagian ini menerangkan keternalaran (kerasionalan) mengapa topik yang dinyatakan pada judul karya tulis ilmiah itu diteliti. Untuk menerangkan keternalaran tersebut maka dijelaskan terlebih dahulu pengertian topik yang dipilih. Baru kemudian diterangkan argumen yang melatarbelakangi pemilihan topik itu dari sisi substansi dalam keseluruhan sistem substansi yang melingkupi topik itu. Dalam hal ini dapat dikemukakan misalnya adanya kesenjangan antara harapan dan kenyataan, antara teori dan praktek.

Secara sederhana, Silverman (2005: 292) mengatakan bahwa latar belakang berfungsi untuk mengarahkan pembaca sebagaimana fungsi abstrak. Dengan mengutip Murcott (1997:1), Silverman menjelaskan bahwa latar belakang harus menjawab pertanyaan: (1) Mengapa anda memilih topik ini dan tidak yang lain; (2) Mengapa topik ini menarik bagi anda; (3) Jenis pendekatan atau disiplin tertentu yang akan digunakan; dan (4) Pertanyaan atau masalah penelitian.

Dengan cara yang berbeda, latar belakang dalam pendahuluan biasanya terdiri dari beberapa elemen. Swales dan Feak (1994) dan Bunton (2002) dalam (Paltridge dan Sairfield, 2007) menggambarkan move yang ada dalam pendahuluan sebagai berikut:

- Move 1: menjelaskan territorial kajian; (a) dengan memperlihatkan bahwa bidang penelitian secara umum penting dan sentral, problematis, menarik atau relevan dalam satu atau lain hal; (b) dengan memberikan informasi yang menjadi latar belakang tentang topik penelitian; (c) dengan memperkenalkan dan menelaah hasil karya penelitian sebelumnya dalam bidang yang dikaji; (d) dengan mendefinisikan istilah

- Move 2: menentukan tempat atau posisi penelitian; (a) dengan mengindikasikan kesenjangan dalam penelitian se- 
belumnya, memunculkan pertanyaan tentang kesenjangan itu, atau bisa juga menambah pengetahuan sebelumnya; (b) dengan mengidentifikasi masalah atau kebutuhan.

- Move 3: menempati tempat atau posisi penelitian; (a) dengan menyatakan tujuan penelitian atau hakikat penelitian yang dilakukan atau pertanyaan penelitian atau hipotesa; (b) dengan menyatakan temuan utama atau manfaat penelitian; (c) dengan menjelaskan strukur tulisan dan memberikan sinopsis mini atau preview dari bab-bab selanjutnya; (d) dengan menyatakan posisi teori; (e) dengan menggambarkan metode penelitian yang dipakai.

Move inilah yang menjadi inti kerangka teori dalam penelitian ini terutama untuk melihat sejauh mana elemen tersebut hadir dalam latar belakang pendahuluan skripsi mahasiswa dari perguruan tinggi. Kecakapan penulis dalam menuangan elemen tadi kemudian dikaji lagi dengan melihat sisi pengemasan tulisan berkenaan dengan kohesifitas suatu teks.

\section{Metodologi}

Penelitian ini menggunakan metode penelitian komparatif, yakni sejenis penelitian deskriptif yang ingin mencari jawaban secara mendasar tentang sebab-akibat, dengan menganalisis faktor-faktor penyebab terjadinya ataupun munculnya suatu fenomena tertentu (Nazir, 2005: 58). Dalam penelitian ini peneliti mengkaji penulisan background skripsi yang ditulis oleh mahasiswa Sastra Inggris UIN Bandung dan Sastra Inggris Universitas Negeri Medan dengan membandingkan aspek move yang dikembangkan dan juga kelebihan serta kekurangan yang terdapat dalam kedua sumber tulisan tersebut.

Sumber data dalam penelitian ini berupa tulisan background mahasiswa Sastra Inggris dari kedua universitas. Jumlah tulisan yang diteliti masing-masing sebanyak 8 buah pada masa sidang tahun 2015 yang memang jumlahnya masih terbatas. Pemilihan data ini didasarkan pada keterbaruan data yang memungkinkan tampilnya tren penulisan yang terkini sehingga mengurangi bias 
dalam penelitian ini.

Berikut ini adalah judul-judul skripsi dari kedua universitas yang tulisan backgroundnya diambil sebagai data:

\section{UIN Bandung (\#):}

\#Data 1 The Perceptive and Expressive Language Disorder in the Main Character of I am Sam Movie

\#Data 2 Building Tasks in Putra Nababan's Interview with Barrack Obama

\#Data 3 English Neologism and Indonesian Translation: A Study in The Social Network Movie

\#Data 4 The Social Stratification in Charles Dicken's Oliver Twist

\#Data 5 The Meaning of Metaphor in Bruno Mars' Doo-Woops \& Holigans Album

\begin{tabular}{ll}
\hline \#Data 6 & Phrasal Verbs in George Orwell's 1984 and Its Arabic Translation \\
\hline \#Data 7 & $\begin{array}{l}\text { Readers' Understanding of Political Terms in the News of The } \\
\text { Jakarta Post Newspaper }\end{array}$ \\
\hline \#Data 8 & $\begin{array}{l}\text { A Semiotic Analysis of Indonesian Beauty Soap in Internet Adver- } \\
\text { tisement }\end{array}$
\end{tabular}

\section{Universitas Negeri Medan (*):}

*Data 1 Figurative Meaning in the Banquets Movie

*Data 2 Textual Function in The Jakarta Post Editorials

*Data 3 Semiotic Analysis of A Mild 'Go Ahead' Version on Television

*Data 4 Tenor in Jokowi and Ahok's Conversation

*Data 5 Turn-Taking in Hitam Putih Talk Show

*Data 6 Jargon Used by Police in Namo Rambo Police Quarter

*Data 7 Metaphor in Nighwish's Dark Passion Play Album

*Data 8 Conversational Implicature in Inception Movie Dialogue

Pada bagian pembahasan, judul-judul di atas selanjutnya akan disingkat dalam bentuk kode data sebagaimana yang telah ditunjukkan. 


\section{Move dalam Background Skripsi Mahasiswa UIN Bandung}

\section{\#Data 1}

Bagian pendahuluan dalam judul ini dibuka dengan pernyataan umum tentang bahasa, "Language is one of ways to interact with other persons" di kalimat pertama. Pernyataan ini kemudian dilanjutkan dengan tiga kalimat berikutnya di paragraf pertama yang secara linguistik kurang kohesif. Paragraf pembuka ini terlalu umum dan jauh dari topik yang akan dikaji tentang language disorder dan juga dari move 1 yang seharusnya menjelaskan tentang wilayah kajian.

Wilayah/teritorial kajian mulai tampak pada paragraf kedua. Masih dalam paragraf yang sama, penulis lebih lanjut menjelaskan tentang apa yang dimaksud dengan language disorder dan gejala yang biasa menghinggapi penderita kekurangan ini. Secara spesifik pemaparan ini menunjukkan kategori $d$ dalam move 1, yakni mendefinisikan istilah.

Paragraf berikutnya diawali dengan kutipan tentang language disorder sebagai salah satu kekurangan yang juga dialami oleh penderita autis. Hal ini kemudian diikuti dengan pengerucutan masalah dengan melihat pada konteks yang sama yang terjadi di salah satu tokoh di film yang ia kaji. Sampai titik ini pembahasan masih berada pada tahap move 1 bagian $b$ berupa informasi yang melatarbelakangi topik penelitian.

Paragraf selanjutnya seharusnya menjadi titik tolak pergerakan menuju move 2 untuk menentukan posisi penelitian. Sayangnya uraian panjang tentang berbagai penelitian sebelumnya pada topik yang sama tidak diikuti dengan penjelasan tentang celah yang kosong dari studi-studi tersebut untuk ia isi dengan penelitiannya. Inilah sebenarnya inti dari move 2 .

Dua paragraf terakhir berisi tentang pentingnya meneliti topik yang ia kaji dengan alasan yang cukup sederhana yaitu untuk menambah pengetahuan. Tidak ada kriteria move 3 pada bagian ini. Sementara itu paragraf terakhir ditutup dengan pernyataan tentang topik dan judul penelitiannya. 
Dari uraian di atas dapat disimpulkan bahwa tulisan background ini kurang memiliki pola move yang jelas dan cenderung menumpuk di move 1. Hal ini menunjukkan kurangnya pengaturan gagasan yang baik terutama penempatan elemen pendahuluan yang seharusnya ada.

\section{\#Data 2}

Skripsi dengan background yang cukup panjang ini dibuka dengan pernyataan tentang fungsi dan definisi bahasa di enam paragraf pertama. Di paragraf ke tujuh pembahasan mulai masuk ke topik yang ia tuju dengan kalimat pembuka "Talking about language there is the more specified field to analyze text called discourse analysis".

Jika merujuk pada pola move, maka penjelasan tentang teritorial kajian (move 1) sebenarnya baru dimulai di paragraf ini, dimana penulis kemudian menjelaskan tentang konsep discourse analysis, definisi, dan fungsi hingga paragraf ke sepuluh. Sampai titik ini kategori move 1 yang dimaksud adalah pendefinisian istilah. Namun pendefinisian istilah ini pun dianggap terlalu panjang hingga memakan empat paragraf.

Di paragraf berikutnya setelah move $1 d$, penulis menyatakan tentang objek penelitiannya yang berupa wawancara, pelaku dalam wawancara, dan materi yang terdapat dalam wawancara tersebut. Bagian ini sesungguhnya tidak termasuk ke dalam move mana pun dan tidak memenuhi salah satu unsur di dalamnya.

Pola move 1 muncul di paragraf berikutnya yang memuat alasan memilih topik tersebut, yakni untuk memperlihatkan bahwa topik yang ia ajukan menarik untuk dikaji, meskipun tidak disinggung apakah ini penting ataupun problematik.

Pembahasan tentang penelitian sebelumnya baru muncul kemudian di paragraf kedua terakhir yang merupakan bagian dari move 1c. Di sini penulis tidak hanya menilai penelitianpenelitian tersebut namun juga melihat celah yang belum dikaji dalam penelitian tersebut dan pada akhirnya mendudukkan posisi penelitiannnya. Hal ini menunjukkan keberadaan move 2 
dan move 3 dalam satu paragraf.

Perbedaan terletak pada posisi pembahasan. Pengidentifikasian kesenjangan mendahului tinjauan atas penelitian terdahulu. Dengan demikian, move 3 tampak mendahului move 2, meskipun secara prinsip hal ini tidak terlalu signifikan dan sedikit menunjukkan permainan bahasa.

\section{\#Data 3}

Skripsi berikutnya mengkaji topik neoligism dan translation. Berbeda dari tulisan-tulisan sebelumnya, skripsi ini dibuka dengan pentingnya penerjemahan yang dibahas dalam dua paragraf pertama. Dengan demikian kedua paragraf ini memiliki fungsi sebagai pemberian informasi yang melatarbelakangi penelitian yang termuat dalam move $1 b$. Informasi ini masih berlanjut hingga paragraf ketiga.

Di paragraf keempat tulisan ini memuat penjelasan tentang definisi neoligism yaitu "a new word or expression or a new meaning for an existing word." Kemudian dilanjutkan dengan efek yang ditimbulkan oleh keberadaannya terhadap penerjemahan dan beberapa contoh neoligism. Pada tahap ini terdapat pergerakan dalam move 1 dari $b$ ke $d$.

Tidak jauh berbeda dari dua tulisan background skripsi sebelumnya, tulisan ini pun diakhiri dengan serangkaian ulasan singkat atas penelitian terdahulu yang diikuti dengan pernyataan tentang penelitiannya sendiri, tanpa didahului dengan identifikasi atas ruang kosong dari penelitian sebelumnya untuk lebih jauh ia teliti. Elemen ini merupakan bagian yang wajib ada sebagai identitas dari move 3.

\section{\#Data 4}

Tulisan background dalam skripsi ini terdiri dari enam paragraf dalam tiga halaman. Paragraf pertama dibuka dengan, "In early society, people share a social standing. They began elevated some groups, community or even someone which has a 
Penulisan Background Skripsi Mahasiswa Bahasa Inggris

higher position in the society." Dari dua kalimat pembuka di atas tampak bahwa penulis sudah masuk ke topik penelitiannya sejak awal.

Selanjutnya di paragraf pertama ini dijelaskan definisi stratifikasi, yang menjadi istilah inti dalam judul, kemudian diikuti dengan penyebab kondisi tersebut. Dengan demikian paragraf pertama ini menjadi penanda move 1 kategori d. Sementara itu di paragraf kedua background mulai memuat informasi tentang stratifikasi sosial di novel yang menjadi objek penelitian. Dijelaskan juga bagaimana stratifikasi sosial tersebut dimunculkan dalam novel. Dapat disimpulkan bahwa aspek inilah yang mendorong untuk mengkaji fenomena tersebut secara lebih mendalam. Paragraf ini juga sekaligus menandai keberadaan move $1 b$.

Sayangnya di paragraf berikutnya pembahasan malah bergerak ke topik umum. Boleh jadi penulis bermaksud mengaitkan antara kondisi stratifikasi sosial tadi dengan sastra sebagai genre dari objek penelitiannya. Namun hal ini membuat alur gagasan menjadi tidak teratur dan cenderung mundur. Ini juga yang menyebabkan pergerakan move menjadi tidak jelas.

Paragraf berikutnya memuat beberapa penelitian sebelumnya yang mengambil objek novel yang sama. Tahapan ini masih menunjukkan move 1 kategori $c$ dalam kondisi yang sedikit berbeda. Di sini penulis tidak menelaah hasil karya penelitian sebelumnya dalam bidang penelitian yang dikaji, namun lebih pada mempresentasikan penelitian-penelitian yang mengkaji novel yang sama.

Di paragraf terakhir penulis menyatakan perbedaan topik yang ia kaji dengan penelitian sebelumnya dan ini menandakan perubahan langkah pada move 2. Namun tidak seperti seharusnya, di sini lagi-lagi penulis hanya memaparkan saja inti penelitianpenelitian tersebut tanpa mengidentifikasi celah yang bisa ia isi untuk penelitiannya. 


\section{\#Data 5}

Move 1 dalam latar belakang skripsi ini mulai tampak di paragraf ketiga. Di dua paragraf sebelumnya penulis menyampaikan pengantar tentang lagu dan penyanyi dan bahasa yang biasa digunakan dalam lirik lagu. Sebagai pembukaan, dua paragraf ini cukup efektif mengantarkan pembaca pada topik yang hendak penulis kaji dengan tidak menyampaikan hal yang terlalu umum.

Di paragraf ketiga move $1 \mathrm{~b}$ tampak dengan kalimat pembuka sebagai berikut, "But in reality, there is a bit of a singer and the listeners who just enjoy what it is wihout understanding the lyrics or impregnating the meaning contained in the lyrics of the song." Di sini ada informasi yang disampaikan oleh penulis tentang hal yang melatarbelakangi penelitiannya.

Kalimat selanjutnya secara gagasan seharusnya menunjang move ini, bukan malah membelokkan gagasan ke arah yang tidak semestinya. Para linguis malah diminta untuk turut mengisi ruang dalam penulisan lirik yang diwarnai dengan bahasa kiasan (figurative language), bukan melakukan kajian terhadap jenis bahasa tersebut.

Paragraf berikutnya juga dibuka dengan kalimat yang sebenarnya kurang tepat secara konsep. Kesalahan ini mengakibatkan pola move kembali menjadi tidak jelas. Boleh jadi paragraf ini, dan juga paragraf berikutnya, masih merupakan bagian dari move $1 b$. Namun sebagian informasi yang disampaikan tampaknya kurang relevan dengan move tersebut. Di paragraf kedua terakhir penulis menyebutkan dua penelitian sebelumnya dalam topik yang sama tentang metafor. Bagian ini masih menunjukkan move 1 di posisi $c$.

\section{\#Data 6}

Gagasan dalam tulisan ini disusun dengan menjelaskan pentingnya bahasa Inggris dan Arab sebagai bahasa internasional yang menunjukkan posisi move $1 b$. Pada paragraf berikutnya tulisan mulai mengerucut pada topik yang ia kaji, yaitu tentang phrasal verb. Pembahasan kemudian dilanjutkan dengan pembe- 
rian contoh phrasal verb dari kedua bahasa. Sampai pada bagian ini pun tulisan masih berada di tingkat move $1 b$.

Baru pada paragraf-paragraf berikutnya tampak perpindahan dalam move 1. Move 1 a mulai muncul di paragraf selanjutnya yang membahas tentang penerjemahan. Salah satu pernyataan yang menandainya adalah, “... it doesn't mean that each phrasal verb in English will always be translated in the same form as phrasal verb into Arabic." Di sini penulis ingin menunjukkan bahwa bidang penelitian secara umum problematik dan menarik untuk dikaji.

Paragraf selanjutnya dalam latar belakang ini memuat ulasan atas penelitian sebelumnya yang juga berada dalam lingkup penerjemahan, hanya saja berbeda dalam topik spesifik dan objek. Penulis menyebut ini sebagai rumpang dalam penelitian terdahulu yang hendak ia isi. Meskipun anggapan atas rumpang ini kurang representatif karena hanya mengambil satu contoh, namun bagian ini dapat dijadikan move 2 dan kalimat terakhir yang menyebutkan posisi penelitiannya menjadi contoh sederhana dari move 3.

\section{\#Data 7}

Dua paragraf pertama memberi pembuka tentang berita dan media dengan maksud untuk mengantarkan pada objek yang dikaji. Dua paragraf berikutnya mulai menyentuh topik kajian tentang political terms dalam berita yang kemudian dihubungkan dengan semantik. Paragraf lima secara khusus membahas definisi semantik dan dinyatakan dalam paragraf enam bahwa peneliti menggunakan makna denotatif, yang merupakan bagian dari semantik, sebagai pendekatan dalam menjawab masalah penelitian.

Dengan mengabaikan kesalahpemahaman konsep pada paragraf keenam, dapat disimpulkan bahwa di enam paragraf penulis berusaha memberikan informasi yang melatarbelakangi topik penelitiannya, termasuk informasi tentang teori yang hendak ia gunakan. Sampai pada paragraf enam ini pembahasan 
latar belakang menunjukkan move $1 b$.

Selanjutnya penulis mengulas satu penelitian sebelumnya yang menurutnya paling relevan dengan topik yang ia kaji. Ini menunjukkan keberadaan move pada move 1c. Hal ini diikuti dengan pernyataan tentang perbedaan antara penelitian tersebut dan penelitiannya. Meskipun tidak berupa identifikasi atas kesenjangan yang terdapat dalam kedua penelitian tersebut, pembahasan dalam paragraf ini dapat dianggap sebagai move $2 a$ dalam bentuk yang sederhana. Namun sayangnya di paragraf terakhir tidak ada indikasi adanya move 3 kecuali informasi tentang responden, alasan pemilihan objek penelitian yang ditutup dengan pernyataan tentang judul penelitiannya.

\section{\#Data 8}

Alur move dalam tulisan ini pada dasarnya tidak jelas. Boleh jadi dikarenakan singkatnya latar belakang yang dibuat atau gagasan yang memang tidak tersusun dengan baik. Lima paragraf di awal menunjukkan posisi move 1. Move $1 b$ tampak di paragraf satu sampai tiga. Sementara itu paragraf empat memperlihatkan move 1 a dengan adanya pernyaataan tentang menariknya kajian iklan sabun. Dan paragraf kelima sedikit banyak menunjukkan move $1 c$ meskipun hanya dengan menyebutkan nama dan judul penelitian saja tanpa pembahasan. Alur move langsung loncat pada move 3, tepatnya $3 a$, di paragraf keenam yang merupakan paragraf terakhir dan hanya satu-satunya paragraf yang mengandung move 3. Ringkasnya, background yang terdiri dari enam paragraf ini mengandung move 1 di lima paragraf dan move $3 \mathrm{di}$ paragraf terakhir.

\section{Move dalam Background Skripsi Mahasiswa UNIMED}

\section{*Data 1}

Tulisan pertama yang akan dikaji mengambil topik makna kiasan (figurative meaning). Background tidak terjebak pada 
pembahasan isu yang umum seperti tentang bahasa, meskipun dibuka dengan kalimat, "People use language to communicate and to express feelings more creatively." Kalimat ini merupakan pembuka terhadap kalimat selanjutnya yang sudah mengarah ke topik penelitian yang secara umum menunjukkan move $1 b$.

Di paragraf kedua pola move berpindah dari $1 \mathrm{~b}$ ke $1 \mathrm{~d}$ yang ditandai dengan mood umum .... is .... (dalam hal ini dibuka dengan figurative meaning is ...). Paragraf ini juga memuat contoh dari beberapa bentuk figurative meaning dan bagian ini masih menunjukkan move $1 d$. Perubahan ke pola move $1 a$ kembali tampak di paragraf enam ketika muncul pernyataan tentang menariknya fenomena ini untuk dikaji lebih lanjut. Sementara paragraf berikutnya memuat ulasan atas empat penelitian terdahulu yang relevan dengan penelitian ini yang menunjukkan perubahan pola move $1 a$ ke $1 c$.

Move $2 b$ muncul di paragraf berikutnya yang menunjukkan keberadaan move $2 b$, mengidentifikasi masalah dan kebutuhan saat membahas tentang film yang menjadi objek penelitiannya yang disertai alasan memilih judul film tersebut. Move 3 hadir di kalimat terakhir di paragraf terakhir ketiga dengan menyatakan tujuan dari penelitian ini. Sementara itu dua paragraf terakhir kembali membahas tentang figurative language yang sebetulnya tidak perlu dan tampak seperti alur maju mundur dalam sebuah cerita. Terakhir dapat disimpulkan bahwa tulisan latar belakang ini memiliki pola move yang lengkap, dimulai dari move $1 b, d, a, c$, $2 b$ dan diakhiri dengan move $3 a$.

\section{*Data 2}

Dua paragraf pertama di background ini dibuka dengan pembahasan tentang teori functional grammar yang di dalamnya tercakup topik tentang textual function. Paragraf ketiga masih membahas teori ini yang mulai dikaitkan dengan keberadaannya dalam teks dan paragraf keempat masih menyajikan uraian yang sama. Empat paragraf pertama ini lebih banyak memberikan informasi tentang teori yang mendasari penelitian ini yang 
sebetulnya tidak terlalu tepat untuk disampaikan di dalam latar belakang dan tidak menunjukkan secara spesifik move tertentu. Penjelasan ini lebih tepat ditempatkan di bagian kajian pustaka. Meskipun demikian, ini tampak sebagai upaya penulis untuk menjelaskan fenomena yang terjadi dalam media (bahasa tulisan) melalui pendekatan teori.

Di paragraf berikutnya penulis mulai menyampaikan kemungkinan adanya masalah dalam pembacaan media cetak khususnya koran dikarenakan bagaimana pesan disusun yang merupakan bagian dari isu theme rheme (fungsi textual). Bagian ini menunjukkan move 1a, bahwa masalah ini menarik untuk dikaji. Paragraf berikutnya juga masih merupakan bagian dari move 1a, dimana penulis menjelaskan alasan memilih topik ini.

Sayangnya di move 1 ini tidak didapati elemen yang seharusnya ada, yakni ulasan atas penelitian sebelumnya. Akibatnya tidak ada bagian yang seharusnya menjadi move 2 sebagai kelanjutan dari move 1c. Sementara itu move $3 a$ hadir di paragraf terakhir yang mengandung tujuan dari penelitian ini.

\section{*Data 3}

Paragraf pertama dalam background skripsi ini memuat move $1 b$ dengan memaparkan informasi yang menjadi latar belakang penelitian ini. Informasi yang disampaikan berupa fakta bahwa komunikasi tidak hanya dilakukan melalui bahasa lisan ataupun tulisan namun juga melalui gambar, suatu bentuk yang menjadi objek penelitiannya. Move ini masih berlanjut hingga paragraf 2. Sementara itu di akhir paragraf ini move berpindah ke 1a untuk menunjukkan bahwa kajian terhadap bidang ini menarik dengan menyatakan, "That's why the visual language as a medium for delivery of ideas, feelings, messages and thoughts as a promortional medium that is easily undersood and highly favored"

Paragraf ketiga menyajikan hubungan antara iklan dan semiotik yang menjadi payung teori dari penelitian ini. Bagian ini sebenarnya tidak termasuk ke dalam move manapun namun 
Penulisan Background Skripsi Mahasiswa Bahasa Inggris

tetap saja relevan dengan pembahasan sebagai teori yang mendasari penelitian. Di akhir paragraf ini, move berpindah kembali ke $1 a$, yaitu dengan menyampaikan alasan memilih topik ini untuk penelitiannya.

Sayangnya tulisan ini tidak memuat penelitian terdahulu yang dapat memberi ruang bagi penulis untuk menentukan posisinya. Dan di akhir tulisan ini juga tidak ditemukan pernyataan apapun yang menunjukkan posisi maupun tujuan penelitian ini. Kesimpulannya adalah bahwa background ini hanya memuat move 1 saja.

\section{*Data 4}

Tiga paragraf pertama dari tulisan ini memuat penjelasan tentang konsep tenor yang disusun secara runtut. Di awal paragraf keempat penulis menyatakan tujuan dari penelitian ini dengan mengambil objek percakapan Jokowi. Bagian ini seharusnya merupakan realisasi dari move $3 a$ yang biasanya ditempatkan di bagian akhir background skripsi. Sementara itu, di sini terdapat perpindahan move ke $1 d$.

Lima paragraf berikutnya menjelaskan lebih lanjut bagaimana tenor dapat dianalisis dalam suatu konteks percakapan. Kemudian diikuti dengan contoh analisis yang diambil dari objek kajian dan penjelasan tentang pribadi ke dua pembicara. Bagian ini sebenarnya tidak menunjukkan move apapun dan kurang relevan untuk ditempatkan di dalam latar belakang penelitian. Paragraf terakhir pun tidak memuat informasi yang seharusnya ada di move 2 maupun move 3, sehingga tulisan background ini dapat dianggap hanya mengandung move 1, dengan sedikit tanda-tanda move $3 a$ di bagian awal tulisan.

\section{*Data 5}

Latar belakang pada tulisan ini memiliki pola pengembangan gagasan yang cukup spesifik dan mengerucut pada topik. Paragraf pertama dan kedua membahas tentang turn-taking sebagai bagian dari kajian tentang conversation yang merupakan 
objek utama kajian pragmatik. Tentu saja secara umum hal ini menunjukkan wilayah kajian, yakni di area pragmatik. Namun jika dispesifikkan lagi ke dalam move, hal ini menjadi agak tidak jelas karena pada satu sisi tampak seperti move $1 d$ dan di sisi lain ada unsur move $1 b$. kemungkinan besar bagian ini lebih cenderung ke $1 b$ yaitu memberikan informasi yang menjadi latar belakang penelitian.

Di dua paragraf berikutnya, latar belakang skripsi ini memuat dua penelitian terdahulu yang membahas tentang turntaking dan dikatakan pula bahwa kedua penelitian tersebut menjadi sumber inspirasi bagi penulis. Jika ditinjau dari segi move maka bagian ini memperlihatkan move 1c yaitu memperkenalkan dan menelaah penelitian sebelumnya dalam wilayah kajian yang sama. Pembahasan pun cukup komprehensif, masing-masing diulas dalam satu paragraf.

Dua paragraf berikutnya secara teoretis, membahas tentang overlaps yang merupakan bagian dari turn-taking. Pembahasan ini sebenarnya tidak perlu dilakukan secara panjang lebar untuk menghindari tumpang tindih dengan bagian kerangka teori. Bagian ini akan lebih baik jika dikaji dengan pendekatan yang lebih praktis. Dari segi move, bagian ini tidak terlalu menunjukkan move apapun seperti yang terjadi pada paragraf-paragraf awal tulisan ini. Poin pentingnya adalah di bagian akhir paragraf ini penulis menyatakan hal yang lebih praktis tentang teori ini yang mendorong penulis untuk melakukan kajian di bidang ini.

In previous research overlaps can spoil the conversation in interview context. But as we usually observe in talk show, overlaps are parts of the entertaining factors. Because it provides laughter and the creativity on-the-spot of thoughts and creates more ideas for the host. This makes the writer wants to conduct a research in analyzing the effect of overlaps in talkshow conversation.

Penggalan paragraf keenam di atas menunjukkan munculnya move 2, yaitu menentukan posisi penelitian dengan cara mengidenifikasi celah dalam penelitian sebelumnya 
yang kemudian ia isi dengan topik yang ia pilih. Dalam hal ini yang dianggap rumpang oleh penulis adalah objek kajian yang kemudian dipilih secara berbeda dari penelitian sebelumnya.

Paragraf dilanjutkan dengan penjelasan tentang objek kajian, alasan memilih objek tersebut dan di paragraf akhir dinyatakan juga tujuan dari penelitian ini. Pernyataan ini menandai keberadaan move $3 a$ dalam tulisan latar belakang ini. Dengan demikian dapat disimpulkan bahwa background ini memiliki pola move yang lengkap.

\section{*Data 6"}

Skripsi ini memiliki latar belakang penelitian yang cukup panjang, yaitu 4,5 halaman. Move $1 \mathrm{~b}$ muncul di dua paragraf pertama yang cukup panjang. Paragraf diawali dengan perrnyataan umum tentang bahasa, kemudian mengerucut pada penggunaan bahasa pada konteks sosial tertentu. Pembukaan ini tampak terlalu umum namun jika dilihat area penelitian yang ada di wilayah sosiolinguisik maka hal ini bisa dimaklumi sebagai jalan bagi penulis untuk sampai pada topik spesifik yang dikaji.

Move berubah ke $1 d$ di paragraf ketiga dengan mendefinisikan sosiolinguistik. Gagasan selanjutnya berkembang di paragraf berikutnya empat sampai enam, yang membahas sosiolinguistik secara lebih detail. Pembahasan teori ini pada dasarnya kurang sesuai untuk diletakkan di bagian latar belakang penelitian yang seharusnya berisi informasi sebagaimana yang dijelaskan dalam pola move.

Di paragraf kedelapan move berpindah ke $1 c$ yang berisi tinjauan atas penelitian terdahulu. Penulis mengulas tiga penelitian yang kesemuanya mengkaji tentang jargon dengan objek yang berbeda-beda. Move ini dijelaskan dengan cukup baik dengan menjelaskan setiap penelitiannya secara detil.

Sayangnya di paragraf sembilan yang juga merupakan paragraf terakhir tulisan ini terlalu banyak gagasan yang disampaikan. Ini dimulai dari informasi tentang objek penelitian, penjelasan kembali tentang jargon yang tampak seperti kembali 
mendefinisikan istilah, kemudian dilanjutkan dengan alasan memilih topik penelitian tersebut, penjelasan tentang penggunaan jargon di kalangan polisi dan diakhiri dengan pernyataan tentang tujuan penelitian di kalimat terakhir. Maka jika dilihat dari segi move, pola yang terbentuk adalah $1 d-1 a-1 b$, kemudian kalimat terakhir bisa dianggap sebagai move $3 a$ dalam bentuk yang sederhana. Kesimpulan dari keseluruhan latar belakang ini adalah pola lengkap move $1 b-1 d-1 c-1 d-1 a-1 b-3 a$, tanpa keberadaan move 2 .

\section{*Data 7}

Secara garis besar, ada tiga move yang teridentifikasi dalam tulisan background sepanjang tiga halaman ini. Yang pertama move $1 d$ yang muncul di awal paragraf kedua. Di dua kalimat pertama penulis memberikan definisi tentang metafora yang kemudian diikuti dengan berbagai situasi dimana metafora sering digunakan terutama dalam karya sastra. Di bagian ini move telah bergerak ke $1 c$ karena memuat informasi yang menjadi latar belakang penelitian. Penjelasan ini berlangsung hingga paragraf empat. Paragraf tiga menjelaskan tentang lagu yang sering mengandung bahasa yang metaforis dan paragraf empat memuat berbagai genre musik yang selanjutnya mengerucut pada genre musik rok yang menjadi objek dari penelitian ini.

Mulai paragraf kelima move berpindah ke $1 a$ untuk memperlihatkan bahwa topik ini dengan pilihan objek kajiannya menarik untuk diteliti. Dijelaskan di paragraf ini bagaimana musik rok tertentu yang sebenarnya mengandung pesan negatif mengemas pesan tersebut dalam bentuk metafora. Di paragraf berikutnya dijelaskan alasan memilih topik tersebut berdasarkan latar belakang di atas.

Kesimpulan dari uraian di atas adalah bahwa hanya terdapat move 1 dalam latar belakang penelitian ini, yaitu move $1 d, b$, dan a. Sementara move 1c yang seharusnya ada dan bersifat wajib menurut Swales \& Feak (1994) terabaikan dalam tulisan ini. Juga move 2 dan 3 yang tak kalah pentingnya tidak juga ditemukan. 


\section{*Data 8}

Penulis mengawali tulisannya dengan paragraf berikut ini:

No doubt that all people communicate through language. Language puts us together in varian of understanding about the meaning of what we felt, what we saw, what we thought, what we informed, and any other things tha could be pulled out with language. Pragmatics concerned with the study of meaning as communicated by a speaker and interpreted by a listener. It had consequently more to do with the analysis of what people meant by their utterance than what the words or phrase in those utterances might meant by themselves.

Paragraf pertama di atas memperlihatkan wilayah kajian (research territory) dengan memenuhi poin b dan d, yakni memberikan informasi yang menjadi latar belakang topik penelitian dan mendefinisikan istilah. Dalam hal ini penulis menyampaikan argumentasi tentang penggunaan bahasa yang terangkum dalam kajian pragmatik dan mendefinisikannya secara singkat.

Paragraf berikutnya membahas tentang implicature dan cooperative principle sebagai fenomena bahasa yang akan selalu ada dalam suatu percakapan. Hal ini masih menunjukkan move 1b. Penulis juga mengutip hasil penelitian terdahulu tentang topik yang sama untuk memperkuat argumentasi sebelumnya. Selanjunya disampaikan pula contoh peristiwa implicature dan contoh percakapan yang diambil dari skrip film yang dikaji.

Sampai tahap ini dapat dilihat bahwa tulisan background ini pada dasarnya telah memuat move 1 tentang wilayah kajian penelitian yang ditunjukkan dengan adanya informasi yang menjadi latar belakang penelitian, telaah atas hasil studi terdahulu, dan mendefinisikan istilah.

Move 3 ditemukan di paragraf yang diawali dengan, "Most of this paper would examine the pragmatic effects of conversational in a film sccript mainly using the philosopher H. P. Grice's theory...The violation of these maxims became the basic whether the conversation is implicature or not." Bagian ini sedikit banyak 
menunjukkan tujuan dari penelitian ini sehingga dapat dikategorikan ke dalam move $3 a$.

Di paragraf selanjutnya pembahasan beralih ke ulasan penelitian terdahulu dengan membahas tiga judul yang semuanya berbicara tentang cooperative principle. Di sini, pola move kembali ke move 1 bagian c. Move ini bersifat wajib untuk mengantarkan ke move berikutnya. Di paragraf terakhir penulis menyatakan perbedaan penelitiannya dengan penelitian sebelumnya. Jika merujuk pada pola move hal ini tidak menunjukkan move apapun, dalam hal ini move 2 yang seharusnya ada. Namun sebagaimana latar belakang penelitian pada skripsi-skripsi yang lain, sepertinya pernyataan ini memang lazim dipakai untuk mengarah pada akhir dari tulisan background tersebut.

\section{Pola Perkembangan Move dalam Background Skripsi Mahasiswa UIN Bandung}

Pada skripsi dengan kode \#Data 1, pola move yang berkembang adalah 1d-1b-1c-1a. Di situ dapat dilihat bahwa tulisan diawali dengan pendefinisian istilah, pemberian informasi yang menjadi latar belakang penelitian, penelaahan atas penelitian dalam bidang kajian yang sama, dan diakhiri dengan penyampaian argumentasi atau pernyataan bahwa topik penelitian penting dan menarik untuk dikaji. Dengan demikian tulisan background ini hanya berputar di antara move 1.

\#Data 2 menampilkan perkembangan move yang lebih dinamis. Tulisan diawali dengan move $1 \mathrm{~d}$ kemudian berlanjut ke move 1a-1c-3a-2a. Ada catatan yang harus diperhatikan bahwa alur move di atas tidak berlangsung sedemikian runtut karena antara move $1 \mathrm{~d}$ dan $1 \mathrm{a}$ terdapat pembahasan yang tidak sejalan dengan move mana pun (lihat bagian A.1. bab ini). Ini berarti bahwa gagasan dalam tulisan ini tidak disusun dengan cukup baik dan cenderung melompat-lompat. Ini juga tampak pada bagian akhir tulisan dimana move 3 mendahului move 2. Namun setidaknya latar belakang ini memuat informasi yang cukup lengkap sebagai pengantar pada topik penelitian. 
\#Data 3 memiliki pola perkembangam move 1b-1d-2b-1c. Pembahasan diawali dengan informasi yang melatarbelakangi penelitian, dilanjutkan dengan mendefinisikan istilah, mengidentifikasi masalah, kemudian menelaah penelitian sebelumnya. Namun seperti biasanya ulasan atas penelitian terdahulu tidak diikuti dengan identifikasi kesenjangan dalam penelitian-penelitian tersebut.

Di tulisan berikutnya dengan kode \#Data 4, pola move yang dikembangkan adalah 1d-1b-1c-3a. Tulisan tampak menunjukkan pola yang teratur dimana move 1 berlangsung secara berurutan disertai telaah penelitian sebelumnya yang memang bersifat wajib. Hanya saja tidak didapati move $2 a$ yang sebenarnya juga penting untuk mengantarkan ke move 3 . Sementara di sini pembahasan langsung menuju move $3 a$ dengan menyatakan tujuan penelitian.

\#Data 5 memuat move yang paling sederhana, yakni $1 \mathrm{~b}$ dan 1c. Hal ini lebih banyak disebabkan oleh kesalahan konsep yang sering didapati dalam tulisan ini sehingga pola move menjadi tidak jelas. Juga disebabkan oleh penyampaian gagasan yang kurang elaboratif sehingga pembahasan cenderung monoton.

Background skripsi berikutnya di \#Data 6 menampilkan pola move 1b-1a-2b-3a. Pola ini hampir sama dengan tulisantulisan sebelumnya yang biasa diawali dengan move $1 \mathrm{~b}$ atau $1 \mathrm{~d}$. Namun yang lebih baik latar belakang penelitian ini memiliki move yang lebih lengkap dan membentuk pola yang berurut meskipun dalam format yang sederhana. Namun tulisan ini masih juga mengabaikan elemen yang bersifat wajib yaitu move $1 \mathrm{c}$ dan $2 \mathrm{a}$.

Tulisan di \#Data 7 memiliki pola move 1 b-1c dan 2a. Yang lebih baik dari tulisan ini adalah keberadaan unsur move yang bersifat pokok, yaitu 1c dan 2a. Tulisan memuat ulasan atas penelitian terdahulu yang kemudian diikuti dengan pengidentifikasian celah dari penelitian-penelitian tersebut, meskipun tidak sama persis dengan yang disampaikan dalam teori. Namun hal ini setidaknya memberi poin positif karena move ini jarang dite- 
mukan dalam latar belakang skripsi mahasiswa.

Skripsi terakhir yang diteliti yaitu \#Data 8 menampilkan pola move $1 \mathrm{~b}-1 \mathrm{a}-1 \mathrm{c}-3 \mathrm{a}$. Yang menarik dari pola ini adalah keberadaan move $3 a$ yang tidak didahului dengan move 2. Artinya tulisan ini telah memuat ulasan penelitian sebelumnya dan langsung berlanjut ke tujuan dari penelitiannya sendiri, tanpa didahului dengan identifikasi rumpang. Dari keseluruhan pola move yang ditampilkan dalam latar belakang skripsi mahasiswa bahasa Inggris UIN Bandung, dapat disimpulkan bahwa tulisan biasanya diawali dengan move $1 \mathrm{~b}$ atau $1 \mathrm{~d}$, kemudian dilanjutkan unsur lainnya dalam move 1 . Bahkan beberapa tulisan hanya memuat move 1 saja. Dalam hal ini, jarang sekali ditemukan move yang lengkap dalam satu tulisan. Keberadaan move 2 dan 3 seringkali tidak beraturan bahkan untuk beberapa kasus move 3 mendahului move 2.

\section{Pola Perkembangan Move dalam Background Skripsi Mahasiswa UNIMED}

Skripsi pertama yang dikaji (*Data 1) menampilkan pola move yang cukup baik yaitu $1 \mathrm{~b}-1 \mathrm{~d}-1 \mathrm{a}-1 \mathrm{c}-2 \mathrm{~b}-3 \mathrm{a}$. Tampak pada pola tersebut bahwa gagasan dalam bentuk move 1 disajikan dengan lengkap, mulai dari penyampaian informasi tentang latar belakang penelitian, pendefinisian istilah, kemudian dilanjutkan dengan penyampaian argumentasi yang menunjukkan menariknya topik ini untuk dikaji dan diakhiri dengan ulasan penelitian terdahulu. Yang kurang dari bagian ini adalah telaah ruang kosong dari penelitian-penelitian yang sudah diulas yang pada dasarnya lebih penting dibanding move $2 b$. Kemudian tulisan diakhiri dengan pernyataan tujuan penelitian yang merupakan realisasi dari move $3 b$.

*Data 2 menampilkan pola move 1a-1c-3a. Sebagaimana analisis tulisan-tulisan sebelumnya, pola ini menunjukkan perkembangan gagasan yang kurang sempurna. Ada satu tahapan yang terlewat dan cukup penting yaitu menempati posisi penelitian yang tertuang dalam move 2 . 
Latar belakang penelitian di *Data 3 menampilkan pola move yang lebih pendek dan sederhana. Pola yang terbentuk adalah $1 \mathrm{~b}-1 \mathrm{a}$. Ini artinya tulisan dibuka dengan uraian informasi yang melatarbelakangi penelitian dan diakhiri dengan pernyataan tentang pentingnya topik ini untuk dikaji. Ini bukan berarti bahwa hanya sedikit yang ditulis dalam background ini. Namun ada beberapa bagian dari tulisan ini yang tidak relevan dengan move manapun sehingga memutus rangkaian move sebelumnya.

*Data 4 memiliki pola move yang tidak kalah pendeknya. Background ini juga hanya memiliki dua unsur move yakni 3a dan $1 \mathrm{~d}$ sebenarnya latar belakang penelitian ini ditulis sebanyak tiga halaman lebih, yang artinya tidak terlalu sedikit. Namun pembahasan terlalu banyak tersita oleh uraian tentang teori yang lebih tepatnya disimpan di kerangka teori (bab 2). Gagasan sebenarnya yang sejalan dengan alur move baru ditemukan di paragraf kelima dan itu pun langsung menuju ke move 3a dengan menyatakan tujuan penelitian. Pembahasan kemudian dilanjutkan dengan pendefinisian istilah yang tampak merupakan kelanjutan dari bagian awal tentang teori yang terpotong oleh tujuan penelitian tadi. Dengan kata lain tulisan ini tidak terlalu berhasil merepresentasikan latar belakang suatu penelitian.

Background selanjutnya yang dikaji adalah *Data 5 yang menampilkan pola move yang lebih lengkap. Pola yang terbentuk adalah 1b-1c-2a-3a. Tulisan ini memiliki pola move yang ideal karena di sini didapati elemen-elemen move yang bersifat wajib, yaitu 1c dan 2a, dan lebih baik lagi karena dilanjutkan ke move 3a. Dengan kata lain tulisan ini merupakan contoh latar belakang penelitian yang baik yang benar-benar memuat informasi yang dibutuhkan untuk memberikan gambaran pada pembaca tentang penelitian ini secara keseluruhan.

Sementara itu move pada *Data 6 menunjukkan pola yang cukup panjang, yaitu $1 \mathrm{~b}-1 \mathrm{~d}-1 \mathrm{c}-1 \mathrm{~d}-1 \mathrm{a}-1 \mathrm{~b}-3 \mathrm{a}$. Pola yang panjang ini tidak lantas menjadikan tulisan ini bagus sampai kita menganalisis apa saja yang ada di dalamnya. Dari pola tersebut dapat dilihat bahwa penjelasan tentang wilayah kajian mengambil 
porsi yang cukup besar dengan memuat semua unsur move 1. Ketiadaan move 2 dalam latar belakang ini menjadi hal yang biasa mengingat hal yang sama terjadi di kebanyakan skripsi yang lain.

*Data 7 hanya memiliki unsur-unsur di move 1 yaitu dengan pola $1 \mathrm{~d}-1 \mathrm{c}$ dan $1 \mathrm{a}$. Meskipun memuat elemen wajib 1c, namun ketiadaan move 2 dan 3 dalam latar belakang penelitian ini menjadikannya timpang dan tidak memberikan pengantar yang jelas akan penelitian ini secara keseluruhan.

Latar belakang penelitian terakhir yang dianalisis adalah *Data 8 yang menampilkan pola move $1 \mathrm{~b}-1 \mathrm{~d}-3 \mathrm{a}-1 \mathrm{c}$. Tidak ada yang istimewa dengan pola ini, bahkan terdapat ketimpangan, yakni move 3 mendahului move 1 bahkan melewatkan move 2 yang memang tidak ada dalam tulisan ini. Tentu saja hal ini akan berakibat pada alur gagasan yang kurang mengalir dan cenderung melompat-lompat.

Dari keseluruhan pola move yang dianalisis dari latar belakang skripsi institusi pembanding, tampak bahwa awal tulisan tidak selalu dibuka dengan move 1 karena terjadi kasus dimana move yang pertama kali muncul justru move 3. Beberapa tulisan hanya memiliki rangkaian move 1 dan hanya beberapa yang memiliki pola yang lengkap. Sebagian di antaranya juga menampilkan pola yang panjang yang pada level tertentu menunjukkan kedinamisan tulisan.

\section{Kelebihan dan Kekurangan Penulisan Background}

Setelah membahas move yang terdapat dalam latar belakang penelitian pada skripsi dari masing-masing institusi, bagian terakhir ini selanjutnya akan kembali menguraikan tulisan tersebut untuk melihat kelebihan dan kekurangan penulisan dengan merujuk pada pola move tadi.

Pada dasarnya latar belakang penelitian pada kedua institusi memiliki pola penulisan yang nyaris serupa. Artinya tidak ada bagian dari keduanya yang membuat salah satunya mengungguli yang lainnya.

Kelebihan yang terdapat pada keduanya adalah permulaan 
tulisan yang selalu bergerak dari move 1 untuk menjelaskan wilayah kajian, baik yang direalisasikan dalam bentuk informasi yang melatarbelakangi penelitian, definisi istilah, maupun pernyataan tentang menariknya topik tersebut untuk dikaji yang menjadi dasar mengapa melakukan penelitian pada topik dan masalah tersebut (Berndtsson et al., 2008). Dari semua background, kebanyakan tulisan diawali dengan move $1 b$.

Hal lain yang positif dari tulisan kedua institusi adalah kebanyakan dari tulisan tersebut sudah menyertakan elemen wajib dari move 1 yaitu 1c yang berisi telaah hasil penelitian sebelumnya. Dari skripsi mahasiswa UIN Bandung hanya satu tulisan yang tidak memuat move tersebut. Sementara dari universitas pembanding ada dua tulisan yang tidak menyertakannya. Meskipun demikian, tidak semua dari background yang menampilkan move $1 c$ mengulasnya dengan baik. Beberapa di antaranya hanya menuliskan judul penelitian dan penulisnya saja. Padahal esensi dari move ini adalah untuk menjelaskan apa yang menjadi fokus dari penelitian sebelumnya dan bagaimana penelitian yang dilakukan sekarang ini mendudukkan posisinya, apakah melengkapi celah yang kosong, memodifikasi metode atau menggunakan metode yang berbeda, atau mungkin hanya berbeda di objek kajiannya saja. Kebanyakan kasus skripsi mahasiswa yang ditemui hanya berbeda di objeknya saja sehingga tidak ada hal yang benarbenar baru.

Sementara itu ada beberapa kekurangan yang penting untuk diperbaiki ke depannya. Yang paling mencolok adalah sering luputnya move 2 dari perhatian para penulis skripsi. Padahal move ini memiliki 2 unsur yang keduanya bersifat wajib. Move 2 merupakan tempat seorang penulis menentukan posisi penelitiannya, yaitu dengan cara mengindikasikan celah dalam penelitian sebelumnya, memunculkan pertanyaan tentang kesenjangan itu, atau menambah pengetahuan sebelumnya. Kemudian yang satu lagi dengan mengidentifikasi masalah atau kebutuhan. Yang sering terjadi adalah gagasan berkutat di move 1 dan kalaupun ada pergerakkan maka move langsung berpindah ke move 3. 
Kekurangan lainnya adalah munculnya pola yang tidak beraturan di beberapa background, seperti di \#Data 2, *Data 4, dan *Data 8. Yang dimaksud tidak beraturan di sini adalah munculnya move 2 atau 3 yang mendahului move 1 atau 2. \#Data 2 menampilkan pola $1 \mathrm{~d}-1 \mathrm{a}-1 \mathrm{c}-3 \mathrm{a}-2 \mathrm{a},{ }^{*}$ Data 4 memiliki pola $3 \mathrm{a}-2 \mathrm{~d}$, dan di *Data 8 pola yang terbentuk adalah $1 \mathrm{~b}-1 \mathrm{~d}-3 \mathrm{a}-1 \mathrm{c}$. Pola yang tidak beraturan tersebut menunjukkan kurangnya keahlian penulis dalam menuangkan gagasan secara jelas dan terstrukur.

Aspek terakhir yang menjadi kekurangan dari tulisan-tulisan ini adalah meskipun isinya sudah memenuhi unsur move, namun secara substansi gagasan yang dituangkan masih seringkali kurang relevan satu sama lain, banyak ditemukan kesalahan konsep dan juga kesalahan grammar yang cukup mengganggu proses pembacaan.

\section{Kesimpulan}

Dari analisis dapat disimpulkan beberapa hal sebagai berikut. Setiap background yang diteliti memiliki unsur di dalamnya yang sesuai dengan teori move. Ini menunjukkan bahwa pada dasarnya penulisan latar belakang penelitian ini sudah sesuai dengan ketentuan tentang apa yang seharusnya dimuat dalam pendahuluan sebuah skripsi.

Adapun perkembangan move di background skripsi mahasiswa UIN pada prinsipnya memiliki pola yang hampir serupa. Tulisan pada umumnya diawali dengan move $1 b$ dan $1 \mathrm{~d}$ dan selanjutnya berkisar di antara move 1 dengan beberapa di antaranya berkembang ke move 2 dan 3 .

Pola selengkapnya dapat dilihat sebagai berikut:

\#Data 1: 1d-1b-1c-1a;

\#Data 2: 1d-1a-1c-3a-2a;

\#Data 3: 1b-1d-2b-1c;

\#Data 4: 1d-1b-1c-3a;

\#Data 5: 1b-1c;

\#Data 6: 1b-1a-2b-3a;

\#Data 7: 1b-1c 2a; dan 
\#Data 8: 1b-1a-1c-3a.

Dari keseluruhan pola move tersebut, dapat disimpulkan bahwa tulisan biasanya diawali dengan move $1 \mathrm{~b}$ atau $1 \mathrm{~d}$ kemudian dilanjutkan unsur lainnya dalam move 1. Bahkan beberapa tulisan hanya memuat move 1 saja. Dalam hal ini, jarang sekali ditemukan move yang lengkap dalam satu tulisan. Keberadaan move 2 dan 3 seringkali tidak beraturan bahkan untuk beberapa kasus move 3 mendahului move 2 .

Sementara itu latar belakang penelitian dalam skripsi dari institusi pembanding menampilkan pola sebagai berikut:

*Data 1: 1b-1d-1a-1c-2b-3a1b-1d-1a-1c-2b-3a;

*Data 2: 1a-1c-3a;

*Data 3: 1b-1a;

*Data 4: 3a-1d;

*Data 5: 1b-1c-2a-3a;

*Data 6: 1b-1d-1c-1d-1a-1b-3a;

*Data 7: 1d-1c-1a; dan

*Data 8: 1b-1d-3a-1c.

Dari keseluruhan pola move yang dianalisis dari latar belakang skripsi institusi pembanding, tampak bahwa awal tulisan tidak selalu dibuka dengan move 1 karena terjadi kasus dimana move yang pertama kali muncul justru move 3. Beberapa tulisan hanya memiliki rangkaian move 1 dan beberapa bahkan memiliki pola yang lengkap. Sebagian di antaranya juga menampilkan pola yang panjang yang pada level tertentu yang sekaligus menunjukkan kedinamisan tulisan. 


\section{BIBLIOGRAPHY}

Crème, P. \& Lea M. R. 2003. Writing at Universiy: A guide for students ( $2^{\text {nd }}$ edition). Philadelphia: Open University Press.

Berndtsson, M. et al. 2008. Thesis Projects - A Guide for Students in Computer Science and Information System 2nd Edition. London: Springer-Verlag.

Litmoren, J. 2010. Common Challenge in Writing a Researh Paper. Tersedia di http://www.selfgrowth.com/articles/commonchallenges-in-writing-a-research-paper Diunduh pada 25 Maret 2015

Oshima, A. \& Hogue, A. 1999. Writing Academic English (Edisi ketiga). Addison Wesley: Longman.

Paltridge, B. \& Satrfield, S. 2007. Thesis and Dissertation Writing in a Second Language: A handbook for supervisors. London: Routledge.

Saehu, Andang. 2008. An Analysis of English Skripsi Writing. Tesis Universitas Pendidikan Indonesia

Silverman, D. 2005. Doing Qualitative Research. London: Sage Publications.

Swales, J. M. \& Feak, C. B. 2008. Academic Writing for Graduates Students. Michigan: The University of Michigan Press.

Zemach, D. E. \& Rumisek, L. A. 2005. Academic Writing: From paragraph to essay. Oxford: Macmillan. 